\title{
SIROSIS HEPATIS \& TUBERKULOSIS PARU : SEBUAH LAPORAN KASUS
}

\author{
${ }^{1)}$ Evy Eryta, ${ }^{2}$ Doni Saputra, ${ }^{3)}$ Dea Vilia Siswoyo \\ ${ }^{1,2)}$ Bagian Ilmu Penyakit Dalam, RSUD Kota Dumai \\ ${ }^{1,2)}$ Jl. Tanjung Jati No.4, Dumai Timur, Kota Dumai, Riau, 28812 \\ ${ }^{3)}$ Fakultas Kedokteran, Universitas Abdurrab \\ ${ }^{3)}$ Jl. Riau Ujung No. 73 Pekanbaru - Riau - Indonesia \\ E-mail : ${ }^{1)}$ evy.eryta@univrab.ac.id ${ }^{3)}$ dea.vilia.s16@ student.univrab.ac.id
}

\section{Kata Kunci: \\ sesak nafas, nyeri dada, sirosis hepatis, TB paru,} batuk

\section{Keywords:}

shortness of breath, chest pain, liver cirrhosis, pulmonary $T B$, cough

\section{Info Artikel}

Tanggal dikirim: $15-1-2021$

Tanggal direvisi: 22-1-2021

Tanggal diterima: 29-1-2021

DOI Artikel:

10.36341/cmj.v4i1.2163

Attribution-NonCommercial

4.0 International. Some rights reserved

\begin{abstract}
ABSTRAK
Telah dilakukan tindakan kepada seorang pasien laki-laki berusia enam puluh dua tahun di bawa ke IGD RSUD Kota Dumai dengan keluhan sesak nafas sejak \pm 2 minggu yang lalu. Pasien mengeluhkan nyeri dada kanan dan nyeri dada dirasasakan seperti ditimpa beban dan tidak menjalar. Pasien mengeluhkan batuk disertai darah sejak 2 hari yang lalu. pasien mengeluhkan perut semakin membesar sejak 1 bulan ini. Pasien juga mengeluhkan nyeri perut disebelah kiri atas. Nyeri sudah lama dirasakan sekitar 6 bulan terakhir. Penatalaksanaan yang diberikan meliputi Non-Medikamentosa yaitu edukasi kepada pasien dan keluarga untuk selalu memakai masker, menutup mulut dengan tissue atau lengan ketika batuk atau bersin, minum obat secara teratur dan tuntas, pola hidup sehat dan kontrol secara teratur. Di samping itu, dilakukan pula penatalaksanaan medikamentosa diantaranya IVFD A Fusin Hepar : Dextrose 5\% 1:1 10 tpm, Omeprazole 1 ap, Furosemid $3 x 1$ ap IV, Combivent 3x1 Resp Nebu, Spironolacton 100 mg 2x1 Tab OR, Propanolol 10 mg 2x1 Tab OR, KSR 1x1 Tab OR, Hepa Q 3x1 Tab OR, Cefotaxim 2x1Vial OR, NAC 3x1 Cap OR, Etambutol 1000mg 1x1 Tab OR, Inj streptomicyn 750 dan Ciprofloxacin 2x500 Tab OR. Berdasarkan anamnesis, pemeriksaan fisik, dan pemeriksaan penunjang maka ditegakkan diagnosis kepada pasien tersebut adalah sirosis hepatis dan TB paru.
\end{abstract}

\begin{abstract}
An action has been taken on a male patient aged sixty-two years who was brought to the ER at the Dumai City Hospital with complaints of shortness of breath since \pm 2 weeks ago. The patient complained of right chest pain and the chest pain felt like a burden had been placed on it and did not radiate. The patient complained of cough with blood since 2 days ago. The patient complained of stomach getting bigger since 1 month. The patient also complained of abdominal pain in the upper left side. Pain has been felt for about the last 6 months. The management provided includes Non-Medical, namely educating patients and their families to always wear a mask, cover the mouth with a tissue or arm when coughing or sneezing, taking medication regularly and thoroughly, healthy lifestyle and regular control. In addition, medical management was also carried out including IVFD A Fusin Hepar: Dextrose 5\% 1:1 10 tpm, Omeprazole 1 ap, Furosemide 3xl ap IV, Combivent 3xI Resp Nebu, Spironolacton 100 mg 2xl Tab OR, Propranolol $10 \mathrm{mg} 2 x 1$ Tab OR, KSR 1xl Tab OR, Hepa Q 3xl Tab OR, Cefotaxim 2xlVial OR, NAC 3xl Cap OR, Ethambutol 1000mg 1x1 Tab OR, Inj streptomicyn 750 and Ciprofloxacin 2x500 Tab OR. Based on the history, physical examination, and supporting examinations, the patient was diagnosed with liver cirrhosis and pulmonary tuberculosis.
\end{abstract}

\section{PENDAHULUAN}

Sirosis adalah suatu keadaan patologis yang menggambarkan stadium akhir fibrosis hepatik yang berlangsung progresif yang ditandai dengan distorsi dari arsitektur hepar dan pembentukan nodulus regeneratif yang terjadi akibat nekrosis hepatoselular [1]. Sirosis hati merupakan penyebab terjadinya 35.000 kematian di Amerika setiap tahunnya [2]. Menurut laporan rumah sakit umum pemerintah di Indonesia, rata-rata prevalensi sirosis hati adalah 3,5\% seluruh pasien yang dirawat di bangsal Penyakit Dalam, atau rata-rata $47,4 \%$ dari seluruh pasien penyakit hati yang dirawat [3]. Lebih dari $40 \%$ pasien sirosis asimtomatis, sirosis ditemukan sewaktu pemeriksaan rutin kesehatan atau pada saat autopsi [4]. Di negara barat, sirosis hati paling sering terjadi akibat alkoholik, 
sedangkan di Indonesia terutama disebabkan oleh infeksi virus Hepatitis B sebesar 40$50 \%$, virus Hepatitis C sebesar 30-40\%, dan $10-20 \%$ tidak diketahui penyebabnya namun termasuk kelompok virus bukan B dan $\mathrm{C}$. Alkohol sebagai penyebab sirosis di Indonesia mungkin frekuensinya kecil sekali karena belum ada data mengenai hal tersebut.

Tuberkulosis (TB) adalah suatu penyakit menular yang disebabkan oleh kuman Mycobacterium tuberculosis. Tuberkulosis merupakan masalah kesehatan didunia walaupun telah dilakukan upaya pengendalian dengan strategi Directly Observed Treatment Short-course (DOTS) di banyak negara sejak tahun 1995 [4]. Tuberkulosis masih menjadi masalah kesehatan masyarakat yang menimbulkan kesakitan, kecacatan, dan kematian yang tinggi sehingga perlu dilakukan upaya penanggulangan [5].

\section{LAPORAN KASUS}

Pasien datang ke RSUD Dumai via IGD dengan keluhan sesak nafas sejak \pm 2 minggu yang lalu. Sesak nafas dirasakan saat istirahat dan beraktivitas. Pasien mengeluhkan nyeri dada kanan, nyeri dada dirasasakan seperti ditimpa beban dan tidak menjalar. Pasien mengeluhkan batuk disertai darah sejak 2 hari yang lalu SMRS. Pasien juga mengeluhkan batuk berdahak yang tidak sembuh-sembuh selama lebih kurang 3 bulan terakhir, dan mengganggu aktivitas sehari-hari.

Selain itu pasien mengeluhkan perut semakin membesar sejak 1 bulan ini. Pasien juga mengeluhkan nyeri perut disebelah kiri atas. Nyeri sudah lama dirasakan sekitar 6 bulan terakhir. Nyeri dirasakan mendadak seperti ditusuk-tusuk. Pasien juga mengatakan sering cepat kenyang ketika makan. Pasien mengeluhkan matanya menguning, tetapi pasien tidak ingat sejak kapan mulai menguningnya. Mual (-), muntah (-), nafsu makan menurun (+). Pasien mengeluhkan kakinya terasa membengkak. Gangguan BAK (urin pasien berwarna seperti teh pekat), BAB normal, demam (-).

\subsection{PEMERIKSAAN FISIK \\ - Status generalisata}

Keadaan umum

: Tampak sakit

sedang

Kesadaran

: Komposmentis

Tanda vital

$\checkmark$ Tekanan darah $: 130 / 80 \mathrm{mmHg}$

$\checkmark$ Pernafasan $: 26 \mathrm{x} / \mathrm{menit}$

$\checkmark$ Nadi $: 102 \times /$ menit

$\checkmark$ Suhu $\quad: 36,7^{\circ} \mathrm{C}$

Berat badan $\quad: 70 \mathrm{~kg}$

Tinggi badan $: 179 \mathrm{~cm}$

BMI/IMT

$: 70:(1,7)^{2}=$

\section{1,87 (normal)}

\section{Kepala}

a) Mata

- Konjungtiva tidak anemis kanan dan kiri

- Sklera ikterik kanan dan kiri

- Pupil isokor kanan dan kiri

\section{* Thorax}

a) Paru-paru (depan)

- Inspeksi : Statis = Dinding dada sama kanan $=$ kiri

Dinamis $=$ Pergerakan dinding dada kanan $=$ kiri

- Palpasi : Vocal fremitus kanan $=$ kiri

- Perkusi $:$ Kanan $=$ sonor

$$
\text { Kiri }=\text { sonor }
$$

- Auskultasi : Kanan = Bronkial, rhonki (+), wheezing (-)

Kiri $=$ Bronkial, rhonki (+), wheezing (-)

b) Paru-paru (belakang)

- Inspeksi : Statis = Simetris dada kanan $=$ kiri

Dinamis $=$ Pergerakan dinding dada kiri $=$ kanan

- Palpasi : vocal fremitus kanan $=$ kiri

- Perkusi : Kanan $=$ sonor

Kiri $=$ sonor

- Auskultasi : Kanan = Bronkial, rhonki (+), wheezing (-)

Kiri $=$ Bronkial, 
c) Jantung

rhonki (+), wheezing (-)

- Inspeksi : Ictus cordis tidak terihat

- Palpasi : Ictus cordis teraba 2 jari medial linea midclavicularis sinistra ICS V

- Perkusi :

$>$ Batas atas : ICS III Linea parasternalis sinistra

Batas kanan : ICS IV Linea sternalis dextra

> Batas kiri : ICS V Linea midclavicularis sinistra

- Auskultasi : Bunyi jantung S1 S2 reguler, gallop (-), murmur (-)

* Abdomen

- Inspeksi

Perut

- Auskultasi

: Bising usus (+)

- Palpasi

: Supel, nyeri

tekan hipokondrium kiri (+), pemeriksaan hepar (ukuran 2 jari dibawah arcus costarum, tepi tumpul, permukaan tidak rata), pemeriksaan lien (ukuran membesar $\mathrm{S}=5$ )

- Perkusi : redup

- Pemeriksaan asites: undulasi (+)

\section{Ekstremitas}

- Superior : Akral hangat, CRT < 2 detik, edema (-/-)

- Inferior : Akral hangat, CRT $<2$ detik, edema $(+/+)$

\subsection{PEMERIKSAAN PENUNJANG}

\begin{tabular}{|c|c|}
\hline 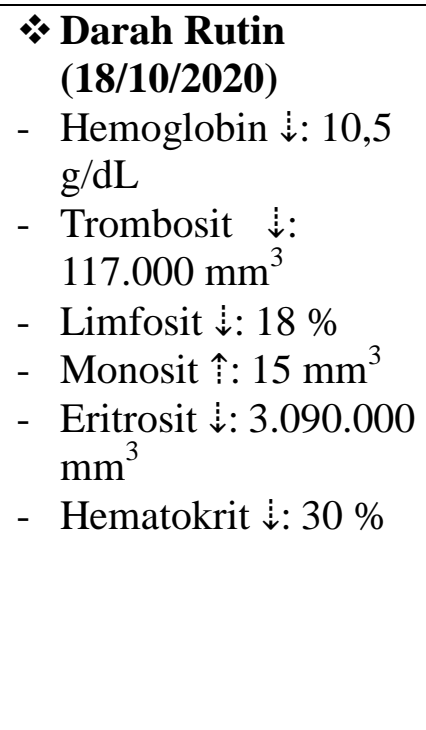 & 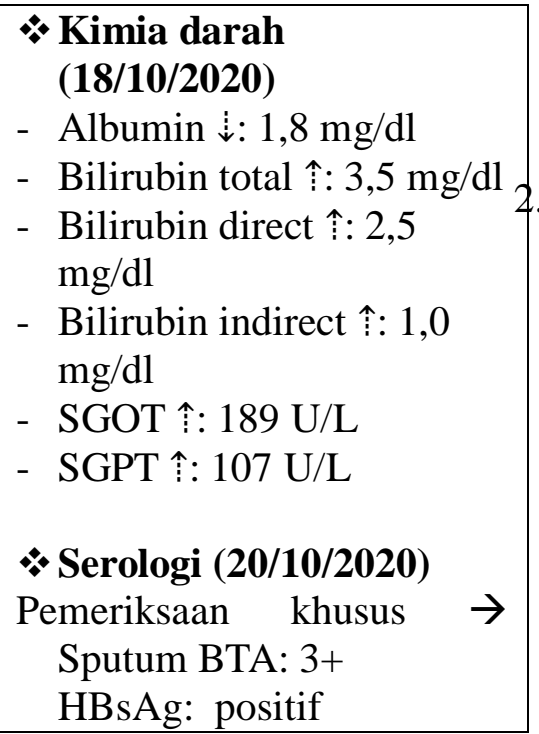 \\
\hline
\end{tabular}

Foto Thorax (18/10/2020)

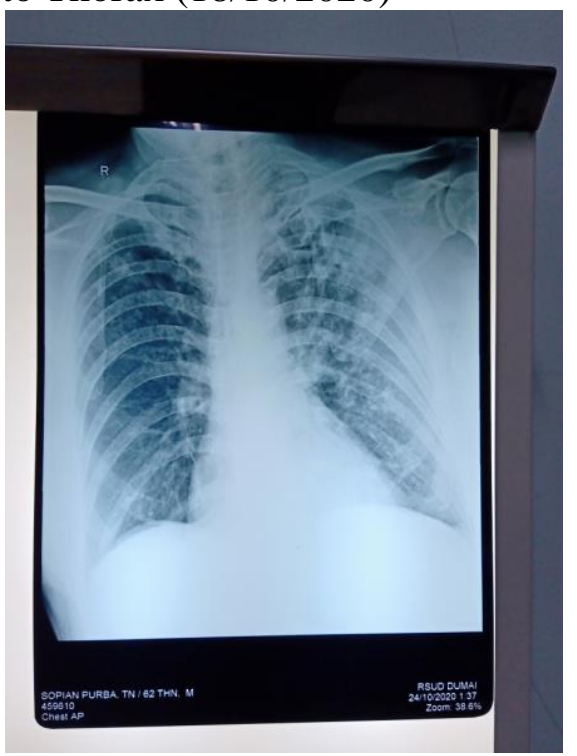

Kesan : TB paru

\subsection{DIAGNOSIS}

TB Paru + Sirosis Hepatis

\subsection{DIAGNOSIS Banding}

Pneumonia, hepatoma

\section{METODE PENATALAKSANAAN}

1. Non-Medikamentosa

- Edukasi kepada pasien dan keluarga untuk selalu memakai masker

- Menutup mulut dengan tissue atau lengan ketika batuk atau bersin

- Minum obat secara teratur dan tuntas

- Pola hidup sehat

- Kontrol secara teratur

. Medikamentosa

- IVFD A Fusin Hepar : Dextrose 5\% 1:1 10 tpm

- Omeprazole 1 ap

- Furosemid 3x1 ap IV

- Combivent 3x1 Resp Nebu

- Spironolacton 100 mg 2x1 Tab OR

- Propanolol $10 \mathrm{mg}$ 2x1 Tab OR

- KSR 1x1 Tab OR

- Hepa Q 3x1 Tab OR

- Cefotaxim 2x1Vial OR 
- NAC 3x1 Cap OR

- Etambutol 1000mg 1x1 Tab OR

- Inj streptomicyn 750

- Ciprofloxacin 2x500 Tab OR

\section{HASIL DAN PEMBAHASAN}

Sirosis adalah penyakit hati kronis yang dicirikan dengan distorsi arsitektur hati yang normal oleh lembar-lembar jaringan ikat dan nodul-nodul regenerasi sel hati. Nodulnodul regenerasi ini dapat berukuran kecil (mikronodular) atau besar (makronodular) [6]. Sirosis biasanya dimulai dengan adanya proses peradangan, nekrosis hati yang luas, pembentukan jaringan ikat dan usaha regenerasi nodul [1]. Akibat pertumbuhan jaringan ikat dan nodul-nodul tersebut, sirkulasi darah intrahepatik dapat terganggu dan pada kasus yang lanjut dapat menyebabkan kegagalan fungsi hati secara bertahap [6].

Prognosis pada pasien ini dibagi atas:

- Ad vitam : Dubia ad malam

- Ad fungsionam : Dubia ad malam

- Ad sanationam : Dubia ad malam

Diagnosis pasien ditegakkan berdasarkan anamnesis, pemeriksaan fisik, dan pemeriksaan penunjang. Pada anamnesis, didapatkan tanda dan gejala yang dialami pasien sesuai dengan tanda dan gejala Sirosis Hepatis dan TB Paru yaitu: asites, sklera ikterik, nafsu makan menurun, sering cepat kenyang ketika makan, edema pada tungkai, BAK seperti teh, sesak nafas, nyeri dada kanan, \& batuk darah.

Pada pemeriksaan fisik ditemukan sklera ikterik, sesak nafas, perut membesar, pada saat palpasi terdapat pembesaran spleen, undulasi $(+)$, edema tungkai, suara nafas tambahan seperti rhonki pada kedua lapang paru bagian depan dan belakang. Selain itu, hasil dari pemeriksaan penunjang yaitu darah rutin: hemoglobin, trombosit, limfosit, eritrosit, hematokrit menurun, monosit meningkat. Kimia darah: Albumin menurun, bilirubin total, direct, indirect meningkat, SGOT \& SGPT meningkat. Serologi: HBsAg
$(+)$.

Rontgen thorax menunjukkan bahwa adanya infiltrat pada kedua apex paru yang berkesan TB paru. Dari pemeriksaan sputum BTA ditemukan hasil 3+.

Untuk non-medikamentosa yang diberikan pada pasien ini yaitu diberikan: edukasi kepada pasien dan keluarga, memakai masker, menutup mulut dengan tissue atau lengan ketika batuk atau bersin, minum obat secara teratur dan tuntas, mengenali dan menghindari faktor pencetus, pola hidup sehat, kontrol secara teratur. Sedangkan medikamentosa yang diberikan yaitu :

IVFD A Fusin Hepar :

Dextrose 5\% 1:1 10 tpm

- $\quad$ Omeprazole 1 ap

- $\quad$ Furosemid 3x1 ap IV

- $\quad$ Combivent 3x1 Resp Nebu

- $\quad$ Spironolacton $100 \mathrm{mg} 2 \times 1 \mathrm{Tab}$

OR

- $\quad$ Propanolol $10 \mathrm{mg}$ 2x1 Tab OR

- $\quad$ KSR 1x1 Tab OR

- $\quad$ Hepa Q 3x1 Tab OR

- $\quad$ Cefotaxim 2x1 Vial OR

- $\quad$ NAC 3x1 Cap OR

- Etambutol 1000 mg 1x1 Tab

OR
- $\quad$ Inj streptomicyn 750
- $\quad$ Ciprofloxacin 2x500 Tab OR

Pengobatan TB bertujuan untuk menyembuhkan pasien, mencegah kematian, mencegah kekambuhan, dan mencegah terjadinya resistensi kuman terhadap Obat Anti Tuberkulosis (OAT) serta memutuskan rantai penularan [7]. Peraturan menteri kesehatan juga menerangkan target $\mathrm{TB}$ Nasional yaitu eliminasi TB tahun 2035 dan bebas TB tahun 2050 [8]. Sehingga kasus mengenai TB masih harus diperhatikan lebih lanjut.

Sirosis hepatis terjadi akibat adanya cidera kronik-reversibel pada parenkim hati disertai timbulnya jaringan ikat difus (akibat adanya cidera fibrosis), pembentukan nodul degeneratif ukuran mikronodul sampai makronodul. Hal ini sebagai akibat adanya nekrosis hepatosit, kolapsnya jaringan penunjang retikulin, disertai dengan deposit 
jaringan ikat, distorsi jaringan vascular berakibat pembentukan vascular intra hepatic antara pembuluh darah hati aferen (vena porta dan arteri hepatica) dan eferen (vena hepatika), dan regenerasi nodular parenkim hati sisanya [9].

\section{KESIMPULAN}

Berdasarkan Anamnesis, pemeriksaan fisik, dan pemeriksaan penunjang maka ditegakkan diagnosis Sirosis Hepatis dan TB Paru.

\section{DAFTAR PUSTAKA}

[1] Siti Nurdjanah. Sirosis Hepatis. Dalam: Sudoyo AW, Setiyohadi B, Alvi I, Simadibrata MK, Setiati S (eds). Buku Ajar Ilmu Penyakit Dalam. Ed 5 . Jakarta; Departemen Ilmu Penyakit Dalam Fakultas Kedokteran Indonesia. 2009. Page 668-673.

[2] Riley TR, Taheri M, Schreibman IR. Does weight history affect fibrosis in the setting of chronic liver disease?. J Gastrointestin Liver Dis. 2009. 18(3):299-302.
[3] Sulaiman, Akbar, Lesmana dan Noer. Buku Ajar Ilmu Penyakit Hati. Jakarta; Jayabadi. 2007

[4] Soeroso L et al. 2017. Buku Ajar Respirasi. Departemen Pulmonologi Dan Kedokteran Respirasi Fakultas Kedekteran Universitas Sumatera Utara. Medan: USU Press

[5] Alwi N. 2013. Prevalensi Pasien TB Paru Yang Mengalami Hepatitis Imbas OAT Dan Faktor Risiko Yang berhubungan Di RSUP Persahabatan Jakarta Dan RSPG Cisarua Pada Tahun 2012.

[6] Lindseth GN. Gangguan hati, kandung empedu, dan pankreas. Dalam: Price SA, Wilson LM. Patofisiologi : konsep klinis proses-proses penyakit. Ed 6. Jakarta : EGC. 2005. 493-501.

[7] Durand F. 2008. Assesment of prognosis of chirrosis. http://www.medscape.com/viewarticle/57 265933

[8] Kementerian Kesehatan R.I. Pusat Data dan Informasi Kementerian Kesehatan RI: Tuberkulosis. Kementrian Kesehatan RI. Jakarta.2018.

[9] Setiati.S et al, 2018, Ilmu Penyakit Dalam, Jakarta, PAPDI. 